\title{
Thromboprophylaxis in general medical patients
}

\author{
Recommendations of the Thrombosis Guidelines Group of the Belgian Society on Thrombosis and \\ Haemostasis and the Belgian Working Group on Angiology.
}

\author{
Members of the Thrombosis Guidelines Group:
}

Gaston BAELE (UZ, Gent), Jean-Louis DAVID (CHU Sart Tilman, Liège), Maria DE MAESENEER (UZ Antwerpen), Véronique DENEYS (Cliniques Universitaires St-Luc, Bruxelles), Mario-Antonio DICATO (CHU Luxembourg), Laure GILIS (CHU Sart Tilman, Liège), Philippe HAINAUT (Cliniques Universitaires St-Luc, Bruxelles), Cédric HERMANS (Cliniques Universitaires St-Luc, Bruxelles), Kristin JOCHMANS (AZ VUB, Bruxelles), Serge MOTTE (Cliniques Universitaires Erasme, Bruxelles), Marc VAN DER PLANCKEN (UZ Antwerpen), Raymond VERHAEGHE (AZ Gasthuisberg, Leuven), Josef VERMYLEN (AZ Gasthuisberg, Leuven), Karl VON KEMP (AZ VUB, Bruxelles), Jean-Claude WAUTRECHT (Cliniques Universitaires Erasme, Bruxelles), Michel ZICOT (CH Citadelle, Liège).

(Acta Cardiol 2003; 58(I): 4I-42)

\footnotetext{
$\mathrm{T}_{\mathrm{r}-\mathrm{b}}$ he following recommendations concern patients with acute medical illness other than acute myocardial infarction, acute stroke or those admitted to the critical care unit.
}

\section{Outstanding points of the literature}

There are fewer prospective studies on the incidence of deep vein thrombosis (DVT) or pulmonary embolism (PE) in hospitalized medical patients than in surgical patients. Most patients included in trials had acute heart or respiratory failure or infections.

The incidence of systematically detected DVT in acutely ill hospitalized patients not receiving prophylaxis is around $15 \%$ for all DVT and 5\% for proximal DVT.

Most of the patients who develop DVT are asymptomatic and the natural history of subclinical DVT in this setting is unknown.

Low-molecular-weight heparin (LMWH) or lowdose unfractionated heparin (UFH) administered by

Address for correspondence: Serge Motte, Department of Vascular Diseases, Erasme Hospital, Route de Lennik 808 - B-1070 Bruxelles. E-mail: smotte@ulb.ac.be

Received July 12, 2002; accepted for publication October 16, 2002. subcutaneous injection significantly reduces the incidence of subclinical DVT. Studies have not demonstrated a reduction in the incidence of symptomatic DVT or PE, but this may reflect a lack of statistical power in the trials. LMWH is at least as effective as low-dose UFH.

The use of aspirin for DVT prevention in medical patients has not been evaluated prospectively. The use of elastic compression stockings in medical patients has not been evaluated.

\section{Recommendations}

Assessment of the risk for DVT

The risk factors for DVT should be assessed for each acutely ill patient individually. The assessment should take into account the acute illness itself and the pre-existing patient-related risk factors presented in Table 1.

\section{Prophylactic methods}

LMWH's are the preferred agents because they are more convenient than UFH. Not all LMWH's have been extensively studied yet. According to the available data, enoxaparin $40 \mathrm{mg} /$ day administered subcutaneously may 
Table 1. - Patient-related risk factors for DVT

- Age $>75$ years

- Cancer (previous or evolving)

- History of venous thromboembolism

- Obesity

- Varicose veins

- Hormone therapy

(except postmenopausal hormone-replacement therapy)

- Chronic heart failure or respiratory failure

- Inflammatory bowel disease

currently be the preferred agent. Elastic stockings could be of some benefit by extrapolation from data in surgical patients. Aspirin is not recommended.

\section{Thromboprophylaxis in hospitalized bedridden patients}

Prophylactic treatment should be provided for patients with acute heart or respiratory failure or bedridden patients with major acute illness + at least 1 patient-related risk factor for DVT.

\section{Thromboprophylaxis in non-hospitalized bedridden patients}

There are no data regarding non-hospitalized patients but it is likely that the risk for DVT is identical to that in patients hospitalized for a similar acute disease. Prophylaxis could therefore be recommended in bedridden patients with acute heart or respiratory failure or patients with major acute illness + at least 1 patient-related risk factor for DVT.

\section{Duration of thromboprophylaxis and platelet count monitoring}

The duration of prophylactic treatment should be limited to the duration of the acute medical illness which temporarily increases the risk for DVT. The platelet count should be checked once a week beyond the fifth day of LMWH administration.

\section{Clinical benefit and risk of thromboprophylaxis}

Members of the board stress that the benefit of prophylactic treatment must be balanced against the risk for each patient, in particular those who may be at increased risk for bleeding and who have not been properly evaluated in trials (patients with renal failure, low weight or in case of combined treatment with aspirin).

\section{Cost of thromboprophylaxis}

The cost per day of thromboprophylaxis, taking into account the drug acquisition and administration and the control of platelet count is $5.08 €$ and $11.69 €$ for hospitalized and non-hospitalized patients, respectively.

\section{Acknowledgment}

The Thrombosis Guidelines Group thanks dr. M.A. Azerad (Aventis Pharma) for providing the relevant literature.

\section{References}

1. Geerts WH, Heit JA, Clagett GP, Pineo GF, Colwell CW, Anderson FA, Wheeler HB. Prevention of venous thromboembolism. Chest 2001; 119: 132S-175S.

2. Samama MM, Cohen AT, Darmon JY, Desjardins L, Eldor A, Janbon C, Leizorovicz A, Nguyen H, Olsson CG, Turpie AG, Weisslinger N. A comparison of enoxaparin with placebo for the prevention of venous thromboembolism in acutely ill medical patients. N Engl J Med 1999; 341: 793-800.

3. Büller HR, Van Der Meer J, Oudkerk M. CBO guideline "Deep venous thrombosis and pulmonary embolism"; revision of the earlier guidelines; Dutch Organization for Quality Assurance in Hospitals. Ned Tijdschr Geneeskd 2000; 144: 1531-7 (in Dutch).

4. Belch JJ, Lowe GDO, Ward AG, Forbes CD. Prevention of deep vein thrombosis in medical patients by low-dose heparin. Scott Med J 1981; 26: 115-7.

5. Bergmann JF, Neuhart E. A Multicenter randomized double-blind study of enoxaparin compared with unfractionated heparin in the prevention of venous thromboembolic disease in elderly in-patients bedridden for an acute medical illness. Thromb Haemost 1996; 76: 529-34.

6. Dahan R, Houlbert D, Caulin C, Cuzin E, Viltart C, Woler M, Segrestaa JM. Prevention of deep vein thrombosis in elderly medical in-patients by a low molecular weight heparin: a randomized double-blind trial. Haemostasis 1986; 16: $159-64$.

7. Harenberg J, Roebruck P, Heene DL. Subcutaneous lowmolecular-weight heparin versus standard heparin and the prevention of thromboembolism in medical inpatients. Haemostasis 1996; 26: 127-39.

8. Bergmann JF, Caulin C. Heparin prophylaxis in bedridden patients. Lancet 1996; 348: 205-6.

9. Lechler E, Schramm W, Flobach CW. The venous thrombotic risk in non-surgical patients: epidemiological data and efficacy/safety profile of a low-molecular-weight heparin (enoxaparin). Haemostasis 1996; 26: 49-56.

10. Lowe GDO, Greer IA, Cooke TG, Dewar EP, Evans MJ, Forbes CD, Mollan RAB, Scurr JH, de Swier M. Risk of and prophylaxis for venous thromboembolism in hospital patients. Br Med J 1992; 305: 567-74.

11. Gardlund B. Randomised, controlled trial of low-dose heparin for prevention of fatal pulmonary embolism in patients with infectious diseases. Lancet 1996; 347: 1357-61. 